\title{
A simplicidade de um rei: trânsitos de Roberto Carlos em meio à cultura popular de massa
}

\author{
Marcos Henrique da Silva Amaral \\ Orientador: Edson Silva de Farias \\ Dissertação de Mestrado \\ Data da defesa: 14.09.2012
}

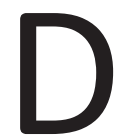
iante do desfile da agremiação carnavalesca Beija-Flor, em 2011, tomado como pináculo da trajetória de consolidação do cantor Roberto Carlos, e do esquema teórico-analítico configuracional de Norbert Elias, esta pesquisa lança mão de uma sociobiografia para compreender, inicialmente, os aspectos sócio-históricos que fizeram as criações do artista sobreviverem ao processo de seleção de uma série de gerações, sendo gradualmente absorvidas no padrão dos produtos culturais subsequentes, à maneira de denominações como o "sertanejo" e o "brega". O recurso à sociobiografia prende-se ao objetivo principal desta pesquisa que é apreender e conceituar as feições da trajetória de "transformação" do "homem" Roberto Carlos no "ídolo" Roberto Carlos, a partir da perspectiva da propagação mundial do pop no escopo da cultura popular de massa, com suas repercussões em um país como o Brasil - na medida em que esta sociedade nacional se remaneja como uma estrutura urbano-industrial e de serviços, em que ganha contornos uma sociedade de consumidores. Fazendo a justaposição entre homem e mito, o trabalho aponta para a trajetória do cantor como figuração do processo de longa duração sócio-histórica de modernização. Destarte, o trabalho adquire relevância teórico-analítica, na medida em que remonta o momento de conformação do espaço social da música popular no Brasil e, ademais, serve como elucidação da forma com a qual os processos de modernização e industrialização do simbólico introjetam novas memórias responsáveis por grandes saltos criativos e sínteses artísticas: enfim, uma reformulação da criatividade musical a partir da própria rearticulação da identidade nacional em torno de uma racionalidade tecnomercantil, que se conjuga a um "novo folclore", já urbano. A consagração de Roberto Carlos como "Rei" passa pela articulação, no âmbito de sua estrutura psíquico-afetiva, de memórias vinculadas ora à racionalidade tecnomercantil da cultura industrializada, ora à dimensão das emoções extraídas de um "folclore aluvial" urbano. Com isso, desenha-se um debate sobre a modernização brasileira, cuja característica é de manutenção do finalismo do espírito religioso, o que nos permite redesenhar teoricamente a construção social do valor de Roberto Carlos, ou seja, sua atribuição de 
"Rei" numa dimensão onírico-mítica. Com efeito, o exercício realizado apontou que o problema da incompatibilidade entre aquilo que acachaparia o popular - a própria racionalidade tecnomercantil - e as matrizes populares diversas é apenas aparente, devendo-se observar a articulação entre ambos como parte de um rearranjo de memórias atrelado ao processo de modernização.

Palavras-chave: Música Popular, Cultura Popular de Massa, Economia Simbólica, Modernização, Roberto Carlos. 